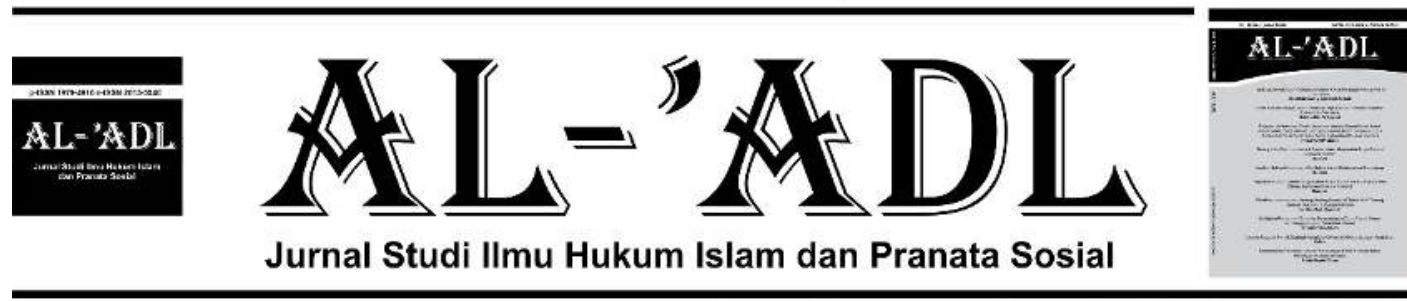

journal homepage : ejournal.iainkendari.ac.id/al-adl

\title{
Paraphilia Exhibitionism between Sharia and Law: A Comparative
} Analysis

Islamul Haq ${ }^{1}$, M Ali Rusdi Bedong², Abdul Syatar'3, Muhammad Majdy Amiruddin

${ }^{1}$ Program Studi Hukum Pidana Islam, Fakultas Syariah, IAIN Pare - Pare, Indonesia

${ }^{2}$ Program Studi Muamalah, Fakultas Syariah, IAIN Pare - Pare, Indonesia

${ }^{3}$ Program Studi Perbandingan Mazhab dan Hukum, UIN Alauddin Makassar, Indonesia

${ }^{4}$ Program Studi Perbankan Syariah, Fakultas Ekonomi dan Bisnis Islam, IAIN Pare - Pare, Indonesia

E-mail: islamulhaq@iainpare.ac.id ${ }^{1}$ malirusdi@iainpare.ac.id ${ }^{2}$ abdul.syatar@uinalauddin.ac.id ${ }^{3}$ muhammadmajdyamiruddin@iainpare.ac.id ${ }^{4}$

\section{ARTICLE INFO}

Article History:

Received: 2020-05-23

Accepted: 2020-10-24

Published: 2020-01-27

Keywords :

Islamic law, Paraphilia

Exhibitionism, Positive law

(C) 2020 Al-'Adl. All rights reserved

\begin{tabular}{l}
\hline ABSTRACT \\
\hline Paraphilia exhibitionism is a form of sexual disorder \\
and immoral offences. This study aims to compare \\
the status of perpetrators of exhibitionism in positive \\
law and Islamic law. This research is qualitative \\
research that uses literature studies. The results \\
showed similarities between Islamic law and positive \\
law on the classification of exhibitionism as a crime. \\
Islamic law and positive law are also similar in terms \\
of ensnaring perpetrators of exhibitionism as \\
someone who can be held accountable. The \\
criminalization aspect of positive law includes \\
exhibitionism as a complaint deliberation. While in \\
Islamic criminal law categorizes the crime of \\
exhibitionism as ordinary deliberation.
\end{tabular}




\section{A. Introduction}

Chris Evan is an actor who plays Captain America in fictional films. On September 13, 2020, the film screened the Twitter trending after allegedly spreading erotic images to millions of followers on Instagram. The incident began when Chris Evan shared footage of his family playing the Heads Up game. However, when the video recording ended, the camera revealed a photo screen showing the gallery, including images that resembled male genitalia. ${ }^{1}$

Cases of exposing the genitals also often occur in Indonesia. One of the cases that attracted enough media attention was the terror committed by a group of men in Karawang by exposing their genitals. The commissioner of the National Commission on Women, Mariana Amiruddin, took this case seriously, who commented that the case was no longer just an aberration, but had led to a crime. ${ }^{2}$ The most recent case that has attracted a lot of media attention is Brusly Wongkar (40), who is happy to show his manifestation activities in front of children in East Cikarang (January 2020). After the examination, the perpetrator was found to have a sex disorder-other cases such as the murder experienced by high school students in Bengkulu. Furthermore, the initial YES (32) case was known to have deviant sexual behaviour. He often made video calls on social media and then showed his genitals to the victim.

Haekal Anshari M.Biomed revealed that the act of showing one's genitals in front of people is a cover for sexual gratification by shocking others. ${ }^{3}$. Brief description in both cases showing the genitals is a sexual disorder known as exhibitionism paraphilia.

Paraphilia is a form of sexual disorder. ${ }^{4}$. Exhibitionism is a mental disorder characterized by a tendency to show nasty things, such as genitals to the opposite sex. It is not uncommon for the perpetrator to physically touch the

\footnotetext{
${ }^{1}$ Rintan Puspita Sari, Peristiwa Memalukan Chris Evans di Instagram, Netizen Heboh, Kompas, September 2020.

${ }^{2}$ Nadia Utami Larasati, "Edukasi tentang Penyimpangan Seksual Eksibisionisme Kepada Siswa/I SMK Nusantara 1 Tangerang Selatan," Simposium Nasional Ilmiah \& Call for Paper Unindra (Simponi), 2019.

${ }^{3}$ Retia Kartika Dewi, Marak Soal Kasus Penyimpangan Seksual, Bagaimana Cara Menghadapinya?, https://www.kompas.com/tren/read/2020/01/27/062900365/marak-soal-kasuspenyimpangan-seksual-bagaimana-cara-menghadapinya-?page=all, accessed June 292020.

${ }^{4}$ Clifford Thomas Morgan, 1976, Brief Introduction to Psychology, Tata McGraw-Hill Education, p. 28.
} 
victim. ${ }^{567}$. An exhibitionist can fantasize sexually and masturbate when he exposes his genitals without touching his victim. In some cases, the exhibitor is often used as a laughing stock, but the exhibitor's action is a severe action that can cause trauma to the victim. ${ }^{8}$

Sexual disorder is one of the social problems that violate the norm of decency ${ }^{9}$ The sexual disorder can also erode the harmony of social life. From a religious and social perspective, sexual disorder will lead to social disorder and immorality, making it difficult to control. The rise of sexual disorder in society hurts the younger generation, especially those at puberty, and affects adults. ${ }^{10}$.

The problem of sexual disorder has become very complicated and unsettling for society; this problem cannot be seen only from a micro perspective. To trace the root of sexual disorder, it is necessary to enter into various aspects of life that affect human behaviour, including sexual crimes. Human behaviour is influenced by factors such as economic, environmental, political, religious, and cultural factors. ${ }^{11}$.

The Criminal Code (KUHP) does not directly mention the crime of exhibitionism paraphilia. There were differences in the judges' interpretation in several cases in determining whether or not the exhibitionists could be held accountable. $^{12}$ The term exhibitionism is not mentioned in the law. Therefore, it is necessary to interpret the elements of exhibitionism in the Criminal Code and the Pornography Law, which is used to ensnare the perpetrators.

${ }^{5}$ Amy B Brunell et al., "Narcissism and Academic Dishonesty: The Exhibitionism Dimension and the Lack of Guilt," Personality and Individual Differences, Vol. 50, No. 3, February 2011, p. 323-28.

${ }^{6}$ Hille Koskela, "Webcams, TV Shows and Mobile Phones: Empowering Exhibitionism," Surveillance \& Society, Vol. 2, No. 2, March 2004, p. 200.

${ }^{7}$ Alwi Hasan, 2005, Kamus Besar Bahasa Indonesia, Balai Pustaka, Jakarta, p. 142.

${ }^{8}$ An Odoemelam, "Incidence and Management of Male and Female Sexually Maladjusted Youngsters: Gender and Counselling Implications," The Counsellor, 1996, 160-71.

${ }^{9}$ Nur Rochmah Dyah Puji Astuti and Yoga Putra Pamungkas, "Deteksi Dini Perilaku Penyimpangan Seksual Menggunakan Metode Forward Chaining Berbasis Web, JIKO (Jurnal Informatika Dan Komputer), Vol. 3, No. 1, Februari 2018, p. 52-58.

${ }^{10}$ Faizah Ali Syobromalisi, "Penyimpangan Seksual dalam Pandangan Islam", Al - Fanar: Jurnal Al-Quran dan Hadis, Mei 2016, p. 1.

${ }^{11}$ Butje Tampi, 2010, Kejahatan Kesusilaan dan Pelecehan Seksual dalam Hukum Pidana Indonesia, Skripsi, Universitas Sam Ratulangi, Manado, p. 1.

${ }^{12}$ Made Sisca Anggreni, I Ketut Rai Setiabudhi, dan Sagung Putri M.E Purwani, "Pertanggungjawaban Pidana Pelaku Tindak Pidana Eksibisionisme dalam Hukum Pidana Indonesia", Kertha Wicara, Vol. 5, No. 1, Februari 2016. 
Exhibitionism is also a mental disorder under the paraphilia. Exhibitionism paraphilia occurs due to the interaction of biological, psychological, and social factors. The question then is, is exhibitionism a punishable as mental illness?

In Islamic law, honour is one of the maqāșid al-syarī'ah that must be maintained. Allah SWT. has forbidden committing offences against someone's honour, such as the prohibition of blood and property. Rasulullah saw. has advised his friend at the end of his life in one of his sermons:

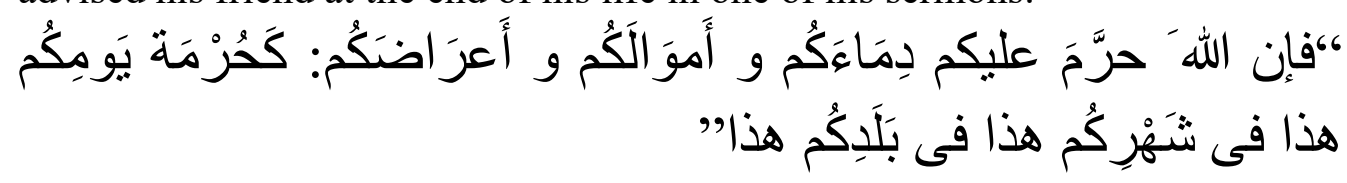

Meanings:

"Indeed, Allah has forbidden on your fellowmen your blood (to be shed) and your property (to be stolen) and honour (to be destroyed). As is haram today, haram is haram this month, and this country is haram".

The classical fiqh scriptures do not talk much about sexual deviant behaviour. Ulama focus on the problem of adultery related to the prohibition law, proof and the threat of punishment. However, the usuliyah rule says: "alwasāil lahā hukmu al-gāyah" (the law of the means/instruments follows the law of the goal). The sexual disorder is one way to get to adultery so that the law follows the adultery law. For this reason, the Islamic law prohibits or orders all things that can protect a person from adultery, such as ikhtilāt (assimilation) between men and women, orders to keep sight, orders to cover genitals, guarding genitals, orders to fast to reduce lust and others so ${ }^{13}$.

Based on this explanation, the authors compare legal studies related to exhibitionism paraphilia sufferers who can be held accountable for positive law and Islamic criminal law.

\section{B. Discussion}

\section{Exhibitionism Paraphilia in Indonesian Law}

People with exhibitionism paraphilia generally act in crowded places. Most of the people with exhibitionism paraphilia are men. At first glance, people with exhibitionism paraphilia do not seem to have mental disorders, even they are usually neat and look for a place to show off their genitals to women or children in order to surprise them. The more shocked their victims

أحمد زنين, “،الموضة و علاقتها بالتحرش الجنسي في الوسط الجامعي,” and أوسامة بلوناس 2017. 
are, then their passion will increase even more ${ }^{14}$. In the era of disruption of exhibitionism, the sufferers' activities have shifted from the real world to the virtual world. People with exhibitionism paraphilia carry out their actions through social media such as video calls via WhatsApp, Facebook, Line, and Telegram ${ }^{15}$

Exhibitionism is a crime that is included in immoral crimes. Although the Criminal Code does not say directly about the crime of exhibitionism, there are articles in the Criminal Code that can be imposed for this crime, namely article 282 of the Criminal Code regarding crimes against decency. Article 282 paragraph (1) of the Criminal Code reads.

"Whoever broadcasts, displays or posts in public the writings, images or objects whose contents are known to violate decency, or who with the intention of broadcasting, showing or posting them in public, makes such writings, images or objects, brings them into the country, passes them on, removing it from the country, or in possession of supplies or whoever openly or by circulating the letter without being asked, offers it or shows it as obtainable, shall be punished by a maximum imprisonment of one year and six months or a maximum fine of three hundred rupiahs ".

Article 10 of Law no. 44 of 2008 concerning Pornogafi reads:

"Everyone is prohibited from presenting himself or others in performances or in public that depict nudity, sexual exploitation, sexual intercourse, or other pornographic content".

Article 36 of Law no. 44 of 2008 concerning Pornogafi reads:

"Anyone who displays himself or another person in a performance or in public that depicts nudity, sexual exploitation, intercourse, or other pornographic content as referred to in Article 10 shall be sentenced to imprisonment of a maximum of 10 (ten) years and a maximum fine. a lot of IDR 5,000,000,000.00 (five billion rupiah)."

Perpetrators of exhibitionism crimes can also be charged under Article 4 of Law no. 44 of 2008, which reads:

"Everyone is prohibited from producing, making, reproducing, duplicating, disseminating, broadcasting, importing, exporting, offering, trading,

${ }^{14}$ Andika Prabowo, Syarifuddin Pettanasse, dan Nashriana Nashriana, 2019, Tinjauan Kriminologi Bagi Seseorang yang Mengalami Gangguan Eksibisionisme, Skripsi, Sriwijaya University, Palembang, p. 3.

${ }^{15}$ Ana Maria Munar, "Digital Exhibitionism: The Age of Exposure", Culture Unbound: Journal of Current Cultural Research, Vol. 2, No. 3, 2010, p. 401-22. 
renting, or providing pornography that explicitly includes, among others: intercourse (including deviant), sexual violence, masturbation (masturbation). , nudity or displays of nudity, genitalia, or child pornography."

The crime of exhibitionism can also be charged with the Information and Electronic Transaction Law (ITE) and its amendments. However, the term pornography is not found in the ITE Law, some articles contain acts that violate decency, namely article 27 paragraph (1) of the ITE Law, which reads:

"Anyone who knowingly and without rights distributes and/or transmits and/or makes accessible Electronic Information and/or Electronic Documents that have content that violates decency".

For criminal threats for violators of Article 27 paragraph (1) of the ITE Law is regulated in Article 45 paragraph (1) of Law 19/2016, namely:

"Anyone who knowingly and without right distributes and/or transmits and/or makes accessible Electronic Information Nand/or Electronic Documents that have contents that violate decency as referred to in Article 27 paragraph (1) shall be sentenced to imprisonment of up to 6 (six). ) years Oand/or a maximum fine of IDR 1 billion".

KUHP, Law no. 44 of 2008 and the ITE Law concerning the regulation of pornography as mentioned above, do not contradict each other. The three regulations above are complementary to one another. The Pornography Law is the lex specialis of the ITE Law and the Criminal Code in pornography crimes committed via the internet. Pornography is a part of the content that violates decency called Article 27 paragraph (1) of the ITE Law and the Criminal Code. ${ }^{16}$.

Exhibitionists include actors who can be held accountable (toerekeningsvatbaar). Although exhibitionism is a mental illness, it is not classified as a person with mental disorders referred to in the Criminal Code Article 44 paragraph (1) and paragraph (2). The exhibitor consciously knows and understands the value of his actions to understand the consequences that will arise from his actions. In the perpetrator, there is dolus exhibitionism or deliberately the same as "willen en wetens". He can determine his own will

\footnotetext{
${ }^{16}$ Sovia Hasanah, Aturan tentang Cyber Pornography di Indonesia, https://www.hukumonline.com/klinik/detail/lt4b86b6c16c7e4/aturan-tentang-cyber-pornography-diindonesia/, accessed January 292020.
} 
for his actions. He is also aware and aware that what he is doing is an act that is prohibited both from a legal perspective and from a social morality perspective. ${ }^{17}$. The disturbance of exhibitionism cannot be used as an excuse to excuse the crime.

According to Abdul Fickar Hadjar, the crime of exhibitionism is a complaint offence, for the legal process. The victim of exhibitionism must report to the authorities about matters that happen to him because exhibitionism is private. Without a report, referring to the articles of sexual immorality, the victim is considered not forced. ${ }^{18}$

Based on the explanation above, exhibitionism in Indonesian law is an immoral crime for which the perpetrator can be held accountable. Exhibitionists understand their actions and understand the consequences of their actions. He realized that the act of exhibitionism violated the law and violated the moral norms of society.

\section{Exhibitionism Paraphilia in Shariah}

Fuqaha did not talk much about sexual disorder, including exhibitionism. They talked more about the law of adultery, the perpetrator of adultery, and the punishment. For example, sexual immorality, known as "altaharrusy al-jinsi", is a new term in fiqh. However, it does not mean that if scholars do not mention the term, then exhibitionism is not regulated in Islamic law. Islam is a religion, and its teachings are perfect and perfect. ${ }^{19}$.

In essence, Islamic law regulates exhibitionism, even if the Islamic legal concept of exhibitionism is traced more broadly than positive law. Nash has shown guidelines so that humanity does not fall into deviant sexual acts. Among the verses of the Koran that can be used as a guide to avoiding exhibitionism are as follows: ${ }^{20}$ :

1. QS al-Nūr/24: 33 which reads:

${ }^{17}$ Satochid Kartanegara, 1960, Hukum Pidana: Kumpulan Kuliah, Balai Lektur Mahasiswa, Jakarta, p. 205.

${ }^{18}$ Vitorio Mantalean, Pakar: Ekshibisionisme Termasuk Tindakan Cabul, Korban Harus Lapor ke Polisi, https://megapolitan.kompas.com/read/2020/01/27/13552941/pakarekshibisionisme-termasuk-tindakan-cabul-korban-harus-lapor-ke?page=all, accessed June 292020 .

${ }^{19}$ Iswan Haris, 2013, Tindak Pidana Pornografi dalam Perspektif Hukum Islam, UIN Alauddin Makassar, Makassar, p. 48.

${ }^{20}$ Didi Junaedi, 2016, Penyimpangan Seksual yang Dilarang Al Quran, Elex Media Komputindo, Jakarta, p. $3-5$. 


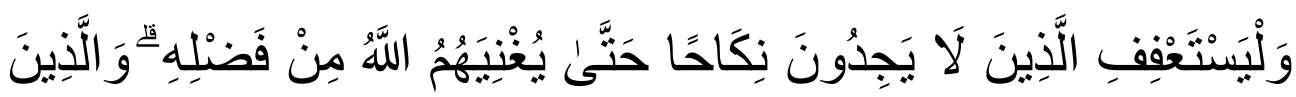

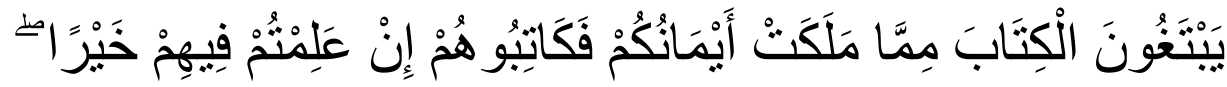

Meanings:

"And let those who do not have the means to marry keep themselves chaste until Allah enriches them out of His bounty. And if any of those 'bondspeople' in your possession desires a deed of emancipation, make it possible for them, if you find goodness in them. And give them some of Allah's wealth which He has granted you. Do not force your 'slave' girls into prostitution for your own worldly gains while they wish to remain chaste. And if someone coerces them, then after such a coercion Allah is certainly All-Forgiving, Most Merciful 'to them".

This verse encourages unmarried people to keep or maintain or maintain the sanctity of their sex life.

2. QS al-Isrā/18: 32 Allah SWT. said:

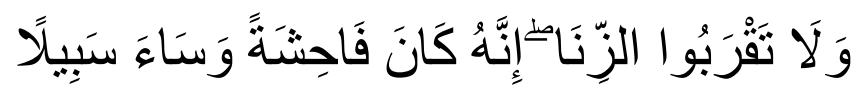

Meanings:

"Do not go near adultery. It is truly a shameful deed and an evil way".

The verse instructs people not to fall into illegal or improper sexual relations. This verse forbids approaching anything stimulating that can lead to adultery.

3. QS al-Aḥzāb/33: 59 Allah SWT. said:

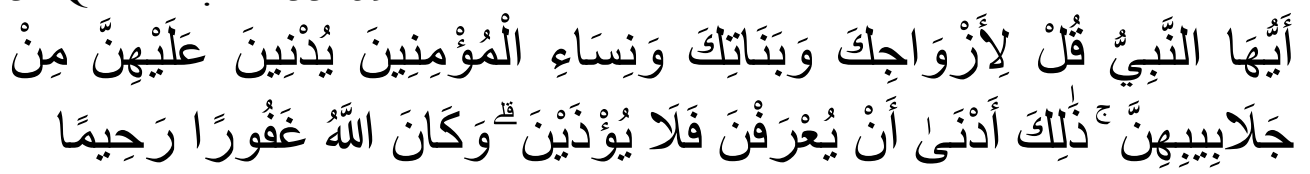

Meanings:

"O Prophet! Ask your wives, daughters, and believing women to draw their cloaks over their bodies. In this way it is more likely that they will be recognized 'as virtuous' and not be harassed. And Allah is All-Forgiving, Most Merciful”.

This verse is a verse that instructs a Muslim always to cover his genitals.

The hadith of the Prophet Muhammad. which reads: 


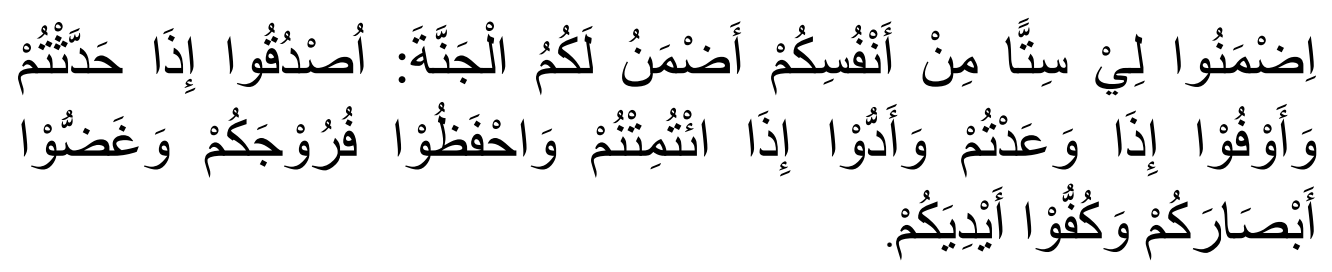

Meanings:

"Assure six things from you for me I will guarantee for you heaven that is honest when you speak, keep (promise) when you promise, fulfil (mandate) when you are given the mandate, keep your genitals, lower your gaze and keep your hands".

These verses and hadith instruct Muslims always to lower their gaze (gaḍd al-abșār). The issue of exhibitionism in Islamic law is closely related to the problem of gaḍ̣ al-abșār, maintaining genitals and dress code. Also, Islamic law is very respectful of human dignity. ${ }^{21}$, even scholars include hifz al-nasb into al-darūriyāt al-khams which must be maintained ${ }^{22}$.

In line with positive law, Islamic criminal law also includes exhibitionists as someone who can be held accountable (taklīf). Performers of exhibitionism cannot be categorized as the madman referred to in the hadith of the Prophet.

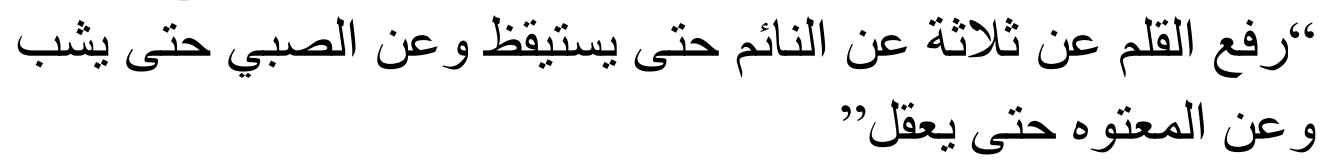

Meanings:

"The pen (recorder of action) was lifted from three conditions: 'One who sleeps until he wakes up, a child until he is an adult and a madman until he is conscious" 23

Exhibitionism in Islamic criminal law can be categorized into takzir related to honour. Islamic law does not explicitly regulate the crime of exhibitionism. However, exhibitionism can be categorized as a takzir because it is an act contrary to the Koran spirit, such as the suggestion of morality, the Beirut, p. 2.

${ }^{21}$ Abdul Qadir Audah, 1987, Al-Tasyri'al-Jinaiy Al-Islamiy, Jil. I, Muassasah Al-Risalah,

${ }^{22}$ Abu Ishaq Al - Syatibi, 2003, Al-Muwafaqat Fi Ushul Al-Syari'ah, Vol. II, Dar Al Kutub Al Ilmiyah, Tt, Beirut, p. 2.

${ }^{23}$ Imam Tirmidzi, 1975, Sunan At-Tirmidzi, Musthafa Bab Al-Halabi, Mesir. 
recommendation always to maintain chastity, avoid things that can lead to adultery, the recommendation to cover the genitals. ${ }^{24}$.

Takzir is an educational punishment whose punishment has not been determined by the shariah. So, all immoral acts that are not the kisas and not hudud can be categorized as takzir. In takzir, the judge is given full authority to sentence the perpetrator according to the severity and lightness of the crime the perpetrator has committed. ${ }^{25}$.

Unlike the positive law which qualifies exhibitionism as a complaint offence, Islamic criminal law makes the crime of exhibitionism an ordinary offence $^{26}$. Islamic criminal law sees exhibitionism as a sin that can destroy the social system of ethics and is against the morals of al Karimah, the dignities of Islam and contrary to the shame that is upheld in Islamic law. Therefore the Islamic criminal law does not make exhibitionism an offence for complaint. The authorities can process the perpetrator even without a report from the victim.

\section{Conclusion}

Exhibitionism is a crime that is included in immoral offences. Exhibitionists in the Indonesian legal system can be charged under the Criminal Code Article 282, Law no. 44 of 2008 article 4, article 10, article 36 and Article 27 paragraph (1) of the ITE Law on pornography regulation. Islamic criminal law considers exhibitionism to be immoral and a crime. Islamic criminal law does not explicitly regulate the crime of exhibitionism. However, it can be categorized as takzir because it is an act contrary to the spirit contained in the Qur'an and Sunnah. The similarities between positive and Islamic law exist in terms of ensnaring exhibitionists as someone who can be held accountable. Exhibitionists know and understand the value of their actions to have consequences contrary to the rules.

The difference between the two lies in the criminal system. Imposing sanctions in positive law that include exhibitionism as an offence for

\footnotetext{
${ }^{24}$ Ahmad Djazuli, 1996, Fiqh Jinayah: Upaya Menanggulangi Kejahatan dalam Islam, RajaGrafindo Persada, Depok, p. 3.

${ }^{25}$ Islamul Haq, "Jarimah Terhadap Kehormatan Simbol - Simbol Negara (Persfektif Hukum Pidana Indonesia dan Hukum Pidana Islam)", Jurnal Syari'ah dan Hukum Diktum, Vol. 15, No. 1, Juni 2017, p $23-42$. 2009.

صالح، جلال الدين محمد مشرف,, “تجريم التحرش الجنسي وعقوبته, . السعيبي، مهند بن حمد بن منصور p26
} 
complaints. A victim of exhibitionism must report to the authorities the sexual harassment incident that she experienced. Without a report, the incident experienced by the victim cannot be legally processed. It is different from the Islamic criminal law which categorizes the crime of exhibitionism as an ordinary offence because it is considered a crime that can damage the social order so that the authorities can process the exhibitionists even without a report from the victim.

\section{REFERENCES}

\section{Books}

Al - Syatibi, Abu Ishaq, 2003, Al-Muwafaqat Fi Ushul Al-Syari'ah, Vol. II, Dar Al Kutub Al Ilmiyah, Tt, Beirut.

Audah, Abdul Qadir, 1987, Al-Tasyri'al-Jinaiy Al-Islamiy, Jil. I, Muassasah AlRisalah, Beirut.

Djazuli, Ahmad, 1996, Fiqh Jinayah: Upaya Menanggulangi Kejahatan dalam Islam, RajaGrafindo Persada, Depok.

Hasan, Alwi, 2005, Kamus Besar Bahasa Indonesia, Balai Pustaka, Jakarta.

Junaedi, Didi, 2016, Penyimpangan Seksual yang Dilarang Al Quran, Elex Media Komputindo, Jakarta.

Kartanegara, Satochid, 1960, Hukum Pidana: Kumpulan Kuliah, Balai Lektur Mahasiswa, Jakarta.

Morgan, Clifford Thomas, 1976, Brief Introduction to Psychology, Tata McGrawHill Education.

Tirmidzi, Imam, 1975, Sunan At-Tirmidzi, Musthafa Bab Al - Halabi, Mesir.

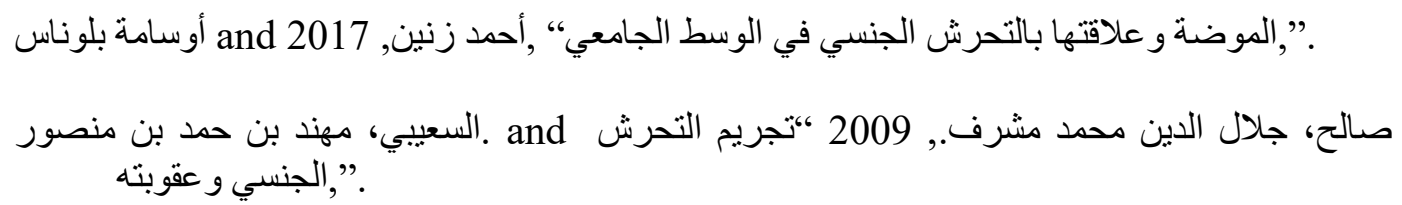

\section{Journal}

Amy B Brunell et al., "Narcissism and Academic Dishonesty: The Exhibitionism Dimension and the Lack of Guilt," Personality and Individual Differences, Vol. 50, No. 3, February 2011. 
Anggreni, Made Sisca, I Ketut Rai Setiabudhi, dan Sagung Putri M.E Purwani, "Pertanggungjawaban Pidana Pelaku Tindak Pidana Eksibisionisme dalam Hukum Pidana Indonesia”, Kertha Wicara, Vol. 5, No. 1, Februari 2016.

Astuti, Nur Rochmah Dyah Puji and Yoga Putra Pamungkas, "Deteksi Dini Perilaku Penyimpangan Seksual Menggunakan Metode Forward Chaining Berbasis Web," JIKO (Jurnal Informatika Dan Komputer), Vol. 3, No. 1, Februari 2018.

Haq, Islamul, "Jarimah Terhadap Kehormatan Simbol - Simbol Negara (Persfektif Hukum Pidana Indonesia dan Hukum Pidana Islam)", Jurnal Syari'ah dan Hukum Diktum, Vol. 15, No. 1, Juni 2017.

Koskela, Hille, "Webcams, TV Shows and Mobile Phones: Empowering Exhibitionism," Surveillance \& Society, Vol. 2, No. 2, March 2004.

Munar, Ana Maria, "Digital Exhibitionism: The Age of Exposure", Culture Unbound: Journal of Current Cultural Research, Vol. 2, No. 3, 2010.

Odoemelam, An, "Incidence and Management of Male and Female Sexually Maladjusted Youngsters: Gender and Counselling Implications", The Counsellor, 1996.

Syobromalisi, Faizah Ali, "Penyimpangan Seksual dalam Pandangan Islam", $A l$ Fanar: Jurnal Al-Quran dan Hadis, Mei 2016.

\section{Newspaper}

Sari, Rintan Puspita, Peristiwa Memalukan Chris Evans di Instagram, Netizen Heboh, Kompas, September 2020.

\section{Symposium}

Larasati, Nadia Utami, Edukasi tentang Penyimpangan Seksual Eksibisionisme Kepada Siswa/I SMK Nusantara 1 Tangerang Selatan, Simposium Nasional Ilmiah \& Call for Paper Unindra, Simponi, 2019.

\section{Thesis}

Haris, Iswan, 2013, Tindak Pidana Pornografi dalam Perspektif Hukum Islam, UIN Alauddin Makassar, Makassar.

Prabowo, Andika, Syarifuddin Pettanasse, dan Nashriana Nashriana, 2019, Tinjauan Kriminologi Bagi Seseorang yang Mengalami Gangguan 
Eksibisionisme, Skripsi, Sriwijaya University, Palembang.

Tampi, Butje, 2010, Kejahatan Kesusilaan dan Pelecehan Seksual dalam Hukum Pidana Indonesia, Skripsi, Universitas Sam Ratulangi, Manado.

\section{Internet}

Dewi, Retia Kartika, Marak Soal Kasus Penyimpangan Seksual, Bagaimana Cara Menghadapinya?, https://www.kompas.com/tren/read/2020/01/27/062900365/marak-soalkasus-penyimpangan-seksual-bagaimana-cara-menghadapinya-?page=all, accessed June 292020.

Hasanah, Sovia, Aturan tentang Cyber Pornography di Indonesia, https://www.hukumonline.com/klinik/detail/lt4b86b6c16c7e4/aturantentang-cyber-pornography-di-indonesia/, accessed January 292020.

Mantalean, Vitorio, Pakar: Ekshibisionisme Termasuk Tindakan Cabul, Korban Harus Lapor ke Polisi, https://megapolitan.kompas.com/read/2020/01/27/13552941/pakarekshibisionisme-termasuk-tindakan-cabul-korban-harus-lapor-ke?page=all , accessed June 292020. 